chromium and nickel, is very difficult to explain on the basis of meteoritic contamination, but could readily result from the presence in the parent material of clay or accessory minerals, containing these elements ${ }^{2}$.

The possibility of two distinctive australite compositions needs further investigation, as well as the relation of the Lake Wilson sample to the nickel and chromium rich tektites in Java, Billiton, Borneo and Cambodia.

Department of Geophysics,

S. R. TAYLOR

Institute of Advanced Studies,

Australian National University, Canberra.

1 Taylor, S. R., Geochim. et Cosmochim. Acta, 26, 685 (1962).

2 Taylor, S. R., and Sachs, M., Geochim. et Cosmochim. Asta (in the press). ${ }^{3}$ O'Keefe, J. A., Tektites (Univ. Chicago Press, 1963).

4 Taylor, S. R., Phys. Chem. Earth, 6 (in the press).

${ }^{5}$ Cherry, R. D., and Taylor, S. R., Geochim. et Cosmochim. Acta, 22, 164 (1961).

- Taylor, S. R., Geochim. et Cosmochim. Acta, 26, 915 (1962).

'Taylor, S. R., and Solomon, M., Geochim. et Cosmochim. Arta (in the press).

Preuss, E., Chem. Erde, 9, 365 (1935).

\section{Argon Retention in a Granitic Xenolith from a Pleistocene Basalt, Sierra Nevada, California}

THIs note reports measurements made in an attempt to determine: (1) the possible effect of xenoliths on wholorock besalt age doterminations; (2) whether or not potassium-argon age determinations on xenoliths in basalt might approximate the age of the basalt flow. The field location is in the canyon of Sawmill Creek, Inyo County, sec. " und 18,T. 12 S., R. 34 E., and soc. 12 and 13 , T. 12 S., R. 33 E. of the temperature of the basalt in about $40 \mathrm{~min}$ ) and argon diffusion dimensions are of the order of the mineral grain size or are subgrain size (for example, for potassium feldspar the diffusion dimension may be 10-30 therefore the size of a xenolith should have very little effect on its argon retention and thus microscopic inclusions could have a significant effect on the potassiumargon age determinod for a whole-rock basalt. The magnitude of the effect would dopend on: (1) the potassium content and age of the basalt; (2) the percentago of the basalt sample that is xenolithic; (3) the amount of radiogenic argon-40 retained by the inclusions; (4) the potassium content and age of the inclusions at the time of solidification of the lava (or more appropriately the argon-40/potassium-40 value).

The effect of xenoliths on the age of a basalt may be estimated using:

$$
T=t_{1}-\alpha \beta t_{2} \frac{\mathrm{K}_{2}}{\mathrm{~K}_{1}}
$$

where $T=$ true age of the basalt, $t_{1}=$ apparent age of the basalt, $\alpha=$ fraction of basalt sample that is xenolithic, $\beta=$ fraction of argon retained by the inclusions, $t_{2}=$ apparent potassium-argon age of the inclusions at the time of solidification of the lava, $K_{2}=$ potassium content of the inclusions, and $K_{1}=$ potassium content of the basalt. This formula will give values within a few per cent of the correct values provided the basalt and the inclusions are Mesozoic or younger, and provided the inclusions comprise less than about 10 per cent of the rock. A more rigorous formula can easily be derived, but because most of the variables must bo estimated a more complicated expression would serve little useful purpose. $t_{1}$ and $\mathrm{K}_{1}$ are measured directly, $K_{2}$ can either be estimated or in some cases can be measured, $t_{2}$ and $\alpha$ can usually

Table 1. Analytioal Data

\begin{tabular}{|c|c|c|c|c|c|c|c|}
\hline No. & Sample & Material & Wt. (g) & $\mathbf{K}(\%)$ & $\frac{\text { Arat }_{40} \times 100}{\text { Arat }_{40}+A^{2} r_{40}}$ & $\operatorname{Arr}_{40} / \mathbf{K}_{40}$ & Age (m.y.) \\
\hline 970 & Basalt & Whole-rock & $19 \cdot 01$ & $1 \cdot 37$ & $99 \cdot 35$ & $0.053 \times 10^{-4}$ & $\begin{array}{l}0.090 \pm 0.090 \\
0.060 \pm 0.050\end{array}$ \\
\hline 980 & $\begin{array}{l}\text { Basalt, argon re-run } \\
\text { Granitic inclusion }\end{array}$ & $\begin{array}{l}\text { Whole-rock } \\
\text { Sanidine }\end{array}$ & $\begin{array}{l}13 \cdot 33 \\
14 \cdot 12\end{array}$ & $6 \cdot 16$ & $\begin{array}{l}99 \cdot 43 \\
52\end{array}$ & $\begin{array}{l}0 \cdot 033 \\
1 \cdot 16\end{array}$ & $\begin{array}{c}0.060 \pm 0.050 \\
2.0 \pm 0.1\end{array}$ \\
\hline
\end{tabular}

Potassium feldspar from a granitic inclusion in an interglacial Pleistocene basalt flow ${ }^{1}$ the probable age of which is less than 100,000 years was analysed for potassium and argon with the rosults shown in Table 1. Presumably the potassium feldspar was originally orthoclase or microcline, but X-ray data show that it has been converted to a sodic sanidine. The inclusion was roughly spherical, about 10 $\mathrm{cm}$ in diameter, and located about $3 \mathrm{~m}$ below the top of the flow, which is approximately $25 \mathrm{~m}$ thick at the sample locality. The source of the xenolith is the Sierra Nevada batholithic complex, which is composed of plutons which range in age from about $80-180$ million years. It is probable, however, that the inclusion came from one of the group of younger plutons and its age before inclusion in the basalt flow most likely is in the range 80-92 million years ${ }^{2}$.

The results show that this potassium feldspar retained about $2 \cdot 0-2 \cdot 5$ per cent of its radiogenic argon assuming a primary age of 80-92 million years. (Potassium feldspars of plutonic origin and/or intermediate potassium content may have retentivities as low as about 50 per cent ${ }^{3}$, thus this feldspar could have had an apparent primary age as low as $40-50$ million years and may have actually retained up to 5 per cont or more of its radiogenie argon.)

Quantitative conclusions about argon retention in xenoliths from basalt flows must await further data, but the measurements presentod here indicate that it is not safe to assume that such xenoliths have been completely degassed of their previously accumulated radiogenic argon. This conclusion leads to the following remarks.

Possible Effects of Xenoliths on Whole-rock Basalt Dates. Heating times are rapid (for example, the centre of a granitic sphere of $10-\mathrm{cm}$ diameter would resch 98 per cent

be estimated, and $\beta$ can be estimated from heat flow and diffusion calculations for each individual case. Hopefully, accurate estimates of $\beta$ under various conditions, for example, depth within a flow, will come from systematic experiments. Note that the age effect of xenoliths on a 10 -million-year old basalt would be small, but the effect of similar inclusions on a 1-million-year old basalt would be increased by a factor of 10 and thus could be largo enough to be significant. Careful inspection for xenoliths should therefore bo a routine part of the petrographic examination of basalt samplos for whole-rock potassium-argon dating.

Use of Xenoliths to date Mafic Volcanic Rocks. If future work leads to the discovery of certain conditions whereby $\beta=0$, it will be possible to use xenoliths, or mineral separates therefrom, to date mafic volcanic rocks that are otherwise undatable. In cireumstances where the factor $\beta t_{2} \frac{\mathrm{K}_{2}}{\overline{\mathrm{K}}_{1}}$ is small compared with $T$, it should be possible to use xenoliths to closely approximate the age of the flow.

The analytical work was done at the Department of Geology and Geophysies, University of California, Berkeloy, and publication is authorized by the I)irector, U.S. Geological Survey.

U.S. Geological Survey,

Menlo Park, California.

${ }^{1}$ Dalrymple, G. B., Ph.D. thesis, Univ. California, Berkeley, Calif, 94 (1963).

Curtis, G. H.. Evernden. J. F., and Lipson, J., Calif. Div. Mines Spec. Rep. 54 (1958). Kistier, R. W. W. (personal communication, 1963).
Rec.

3 Wetherill, G. W., Aldrich, L. T., and Davis, G. L., Geochim. et Cosmochim. Acta, 8, 171 (1955). Evernden, J. F., and Richards, J. R., J. Geol. Soc. Austral., 9, 1 (1962). 4 Evernden, J. F., Curtis, G. H., Kistler, R. W., and Obradovich, J., Amer.
J. Sci., 258, 599 (1960). 